\title{
CORRESPONDENCE
}

\section{DEFORMATION OF THE INCOMPETENT BEDS IN THE PURBECK ANTICLINE}

SIR,--In a recent paper Williams (1961) has considered the movement of incompetent material from the limbs towards the crests and troughs of similar folds. He suggested that the shearing forces at the top of the incompetent bed differ in direction from those commonly accepted.

This provides an explanation of the position of minor folds within the Purbeck Anticline. A generalized reconstruction of the major structure is shown in Text-fig. 1.1 This is based on the Dorset coastal sections assuming a nearly constant easterly plunge. Although complicated by unconformity, disharmonic tendencies are apparent in the anticline. This was perhaps implied by Strahan $(1898$, p. 218) when he suggested that Lulworth Cove lay between a region of compression below and gaping above. The difference in dip (usually at least $30^{\circ}$ ) between the Chalk and the Portland Stone at most of the coastal sections may result from this type of folding.

Williams' shearing forces in such a disharmonic fold are opposite to those produced by normal bed over bed sliding at the top of the incompetent beds, but in a similar direction at the base. If both forces existed during the formation of the Purbeck anticline they would tend to neutralize each other at the top of the incompetent Lower Cretaceous strata and reinforce each other at the base. This would explain the position of the Lulworth and Peveril Crumples, interpreted as drag folds by Arkell (1938), in the Purbeck Beds just above the competent Portland Stone.

\section{REFERENCES}

Arkell, W. J., 1938. Three tectonic problems of the Lulworth District: Studies on the Middle Limb of the Purbeck Fold. Quart. J. Geol. Soc. Lond., 94, pp. 1-54.

Strahan, A., 1898. The Geology of the Isle of Purbeck and Weymouth. Mem. Geol. Surv. Gt. Brit.

Williams, E., 1961. The deformation of confined incompetent layers in folding. Geol. Mag., 98, pp. 317-323.

Department of Geology,

THE UNIVERSITY, SOUTHAMPTON.

26th July, 1963.

$\mathrm{N}$

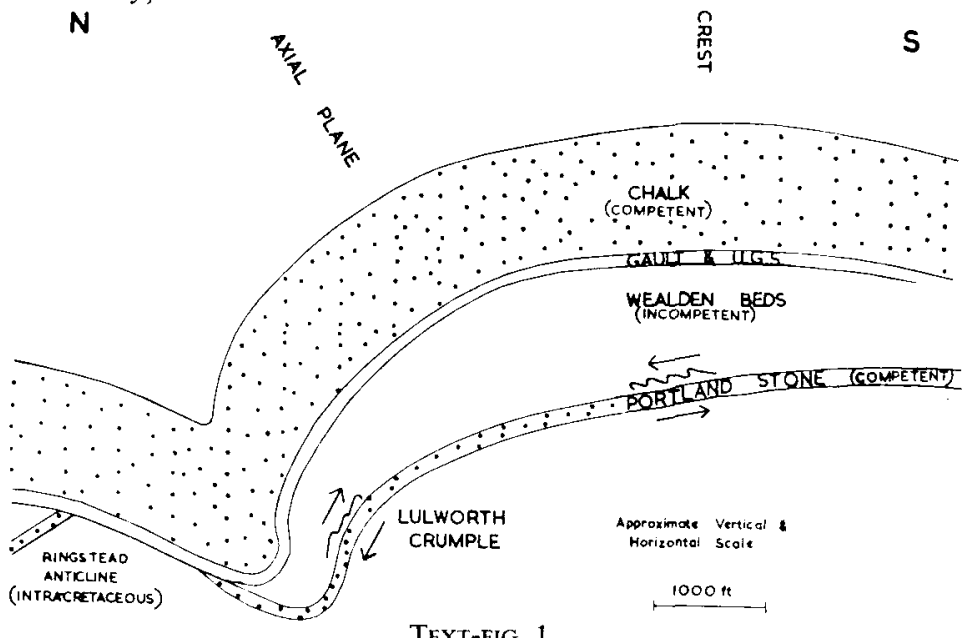

TEXT-FIG. 1.

1 Text-fig. 1 appears here in its correct context. It was mistakenly published with a previous letter in Vol. 101, No. 2, p. 190. 